\title{
WAGE DRIFT AND THE RELEVANCE OF
}

\section{CENTRALISED WAGE SETTING}

\author{
by \\ Steinar Holden* \\ Department of Economics \\ University of Oslo
}

\begin{abstract}
$\underline{\text { Abstract }}$
The system of wage setting in the Nordic countries is often regarded as highly centralised, contributing to considerable real wage flexibility. This view has been questioned, as the sizeable wage drift may offset the effect of the central negotiations. This paper presents evidence from the four major Nordic countries, suggesting that there is no or little such offsetting effect. Yet the institutional system of wage formation may induce nominal rigidities at the central negotiations, that may prevent wage restraint when there is little room for money wage growth. Empirical evidence supports the existence of nominal rigidity.
\end{abstract}

* This paper is part of the research project "Unemployment, institutions and policy" at SNFOslo. The paper draws upon two previous papers, Holden (1991) and Holden and Birkeland (1995). I wish to thank Thea Birkeland for the collaboration in the previous work, and Eilev Jansen, Karl Ove Moene, Ragnar Nymoen, Asbjørn Rødseth, Tore Schweder, Jon Strand, Fredrik Wulfsberg, participants at a presentation in Uppsala, as well as two anonymous referees, for useful comments on earlier drafts. Financial support from the Research Council of Norway is gratefully acknowledged. The numerical results are obtained with PC-GIVE version 8.10, and Limdep version 7.0.

JEL Classification Number: J5.

Keywords: Wage drift, wages, centralisation, nominal wage rigidity. 


\section{Introduction}

The system of wage setting in the Nordic countries is often regarded as highly centralised. However, the wage setting takes place at two levels, nationally or by industry (which I for simplicity will refer to as centralised) and at the firm level (wage drift). 1 Numerically, the two levels have been of about the same importance over the last three decades. This has led some observers to contest the picture of centralised bargaining. Jackman (1990) points out that the wage drift is so large that this "suggests the possibility that centralised wage negotiations may be irrelevant to the final outcome". Lindbeck (1990) and Skånland (1983) argue that a twotiered system leads to higher wages and lower employment than a system with wage setting at one level only.

In contrast, the view that wage setting is centralised is based on the view that the central wage setters take the expected wage drift into account in the negotiations (Hersoug, Kjær and Rødseth, 1986). This view is based on three assumptions: 1) the central wage setters are able to predict the size of the wage drift in advance, 2) the wage drift does not completely offset the effect of the central negotiations, 3 ) the expected wage drift is fully reflected in the increase negotiated at the central level (that is, the actual central increase is given residually from the target wage increase at the central negotiations minus the expected wage drift).

The first of these assumptions seems fairly uncontroversial, and will not be the issue here. The second assumption, that the wage drift does not offset the central agreement, is more important. In previous work (Holden, 1989), I have shown that within a theoretical bargaining model, the institutional feature that strikes and lock-outs are prohibited during the

1 Whether the "central" negotiations are undertaken at national or industry level (or at both levels) varies over time and between countries, but the distinction between national and industry negotiations will not be the focus here. 
local negotiations (due to a peace clause in the central agreement), implies that there will be no such offset. This prediction is supported by Norwegian data (Holden, 1989, and Johansen, 1995). For the other Nordic countries, the evidence is however less clear cut, because most studies have been based on a Phillips curve approach (eg Flanagan, 1990) or used micro data where it is difficult to distinguish the effect of the centrally negotiated wage increase from the effect of outside wages (eg Holmlund and Skedinger, 1990). Hibbs and Locking (1996) find however little offsetting effect of central wage increases on wage drift on Swedish data.

The present paper presents evidence for the relationship between wage drift and centrally negotiated wage increases for aggregate manufacturing for the major Nordic countries, Denmark, Finland, Norway and Sweden. There appears to be no or only a small negative effect of the central increase on wage drift for all countries.

The third assumption, that the expected wage drift is reflected in the central negotiations, has been subject to less empirical research. Hibbs and Locking (1996) find empirical support for this view for Sweden. On the other hand, Flanagan (1990) concludes that drift and central increase are largely independent processes. Theoretical analysis of this relationship is also scant; exceptions are Holmlund (1986), Holden (1988) and Moene, Wallerstein and Hoel (1993).

The present paper investigates the relationship between wage drift and central negotiations within a strategic bargaining framework, and shows that in general the expected wage drift is fully reflected in the central negotiations. However, the institutional framework of the wage setting system (in particular the legal status of a nominal wage contract even after the contract period has expired) may under certain circumstances lead to higher total wages in a two-tiered system than what it would have been in a system with only central wage setting. This reflects the hypothesis of Holden (1991) and Calmfors (1993) that whether a system with 
two-tiered wage setting as the Scandinavian works like a system with only central wage setting, depends on the rate of productivity growth and the rate of international inflation (see also Rødseth, 1985). Basically, the argument is that when there is little room for money wage growth at the central negotiations, due to a large expected wage drift compared to the growth in "target" money wages, downward nominal rigidity at the central negotiations may make wage restraint difficult. More recently, a related view is expressed in OECD Economic Surveys for Finland (1996) and Sweden (1997); the latter reads (page 80) "in the disinflationary climate of the 1990s, real wages have been much more rigid".

The remaining of the paper is organised as follows. The basic model is set out in section 2, while section 3 contains the theoretical analysis. Section 4 contains the empirical evidence on wage drift and the possible existence of a floor on money wages at the central negotiations. Section 5 concludes.

\section{The model}

We consider an economy consisting of $\mathrm{N}$ identical firms, all producing the same good. The economy is completely open, so that the domestic price level $\mathrm{P}$ is exogenously given by the price level in the world market, adjusted for the exchange rate. There is one union in each firm, and at the central level there is a unions' and an employers' association.2

The sequence of moves is as follows. First, the centrally determined wage level $\mathrm{W}_{-1}+$ $\mathrm{C}$ is set in negotiations between the unions' and the employers' federations (where $\mathrm{W}_{-1}$ is the nominal wage from the previous year, and $\mathrm{C}$ is the change in the nominal wage that is agreed

2 I focus on aggregate wages throughout the paper; the system of wage determination may also affect investment, productivity and relative wages (see Moene et al, 1993, and the references therein), which again might have an effect on aggregate wages. These aspects are neglected in the present paper. 
in the central bargain, both assumed to be the same for all firms). Secondly, the local unions negotiate with the management of the firms over local adjustments to the centrally agreed wage level (wage drift, $D_{i}$ ), so that the nominal wage to prevail in firm $i$ is $W_{i}=W_{-1}+C+D_{i}$. Thirdly, each firm employs the number of workers necessary to supply the quantity that is demanded. All agents are assumed to have complete information.

The production function of the firms is assumed to be strictly concave, with employment being the only input. Labour demand and profits of firm $i$ are thus decreasing functions of the real wage in the firm

$$
\begin{array}{ll}
\mathrm{L}_{\mathrm{i}}=\mathrm{L}\left(\mathrm{W}_{\mathrm{i}} / \mathrm{P}\right), & \mathrm{L}^{\prime}\left(\mathrm{W}_{\mathrm{i}} / \mathrm{P}\right)<0, \\
\pi_{\mathrm{i}}=\pi\left(\mathrm{W}_{\mathrm{i}} / \mathrm{P}\right), & \pi^{\prime}\left(\mathrm{W}_{\mathrm{i}} / \mathrm{P}\right)<0 .
\end{array}
$$

A local union's utility is assumed to be a function of the real wage level and the employment level of the firm, $u_{i}=u^{*}\left(W_{i} / P, L_{i}\right)$. Substituting out for (1), we obtain union utility as a function solely of the wage level $u_{i}=u\left(W_{i} / P\right) \equiv u^{*}\left(W_{i} / P, L_{i}\left(W_{i} / P\right)\right)$. Likewise, the utility of the unions' federation can be written as a function of the average real wage level, $v=v(W / P)$ $\equiv \mathrm{v}^{*}(\mathrm{~W} / \mathrm{P}, \mathrm{L}(\mathrm{W} / \mathrm{P}))$, where $\mathrm{L}(\mathrm{W} / \mathrm{P})$ is the average employment level (I shall only discuss symmetric equilibria, so there is no need to distinguish between average and total employment). The utility of the employers' federation is assumed to be given by the average real profits of the firms, $\pi(\mathrm{W} / \mathrm{P})$. 


\section{Local wage bargaining 3}

The wage drift is given by the Nash bargaining solution

$$
\begin{gathered}
\mathrm{D}_{\mathrm{i}}=\quad \arg \max \left\{\left[\pi\left(\mathrm{W}_{\mathrm{i}} / \mathrm{P}\right)-\pi_{\mathrm{i} 0}\right]\left[\mathrm{u}\left(\mathrm{W}_{\mathrm{i}} / \mathrm{P}\right)-\mathrm{u}_{\mathrm{i} 0}\right]\right\}, \\
\mathrm{D}_{\mathrm{i}}
\end{gathered}
$$

where $\pi_{\mathrm{i} 0}$ and $\mathrm{u}_{\mathrm{i} 0}$ are the respective disagreement points. As pointed out by Binmore et al (1986), the disagreement points are given by the parties' payoffs in case of a dispute. In the Nordic countries, the peace clause prohibits strikes and lock-outs within the contract period of the central agreement. Yet the workers may work less efficiently (work to rule), while the firm must pay the centrally agreed wage level $\mathrm{W}_{-1}+\mathrm{C}$. Thus the parties' disagreement points are functions this wage level, $\pi_{\mathrm{i} 0}=\pi_{0}\left(\left(\mathrm{~W}_{-1}+\mathrm{C}\right) / \mathrm{P}\right)$ and $\mathrm{u}_{\mathrm{i} 0}=\mathrm{u}_{0}\left(\left(\mathrm{~W}_{-1}+\mathrm{C}\right) / \mathrm{P}\right)$, where $\pi_{0}^{\prime}<0$ and $\mathrm{u}_{0}^{\prime}>0$. As workers reduce productivity during a work to rule, we have $\pi_{0}\left(\left(\mathrm{~W}_{-1}+\mathrm{C}\right) / \mathrm{P}\right)<\pi\left(\left(\mathrm{W}_{-1}+\mathrm{C}\right) / \mathrm{P}\right)$.

We assume that the Nash product is single-peaked, so that a unique solution exists (this will hold for reasonable specifications of the functional forms). The first order condition to $(3)$ is

$$
\varphi\left(\frac{W_{i}}{P}, \frac{W_{-1}+C}{P}\right) \equiv \frac{\pi^{\prime}\left(\frac{W_{i}}{P}\right)}{\pi\left(\frac{W_{i}}{P}\right)-\pi_{0}\left(\frac{W_{-1}+C}{P}\right)}+\frac{u^{\prime}\left(\frac{W_{i}}{P}\right)}{u\left(\frac{W_{i}}{P}\right)-u_{0}\left(\frac{W_{-1}+C}{P}\right)}=0 .
$$

Since all firms are identical, the resulting wage drift will be the same everywhere. (If firms were different, the resulting wage drift would also differ among the firms. But Proposition 1

3 The wage drift is calculated as a residual in the wage statistics, thus wage drift also includes changes in the average wages due to changes in the employment structure, etc (cf Holden, 
below would still hold.) Implicit differentiation of (4) with respect to $C$ yields $\varphi_{1} \partial\left(\mathrm{W}_{\mathrm{i}} / \mathrm{P}\right) / \partial \mathrm{C}$ $+\varphi_{2}(1 / \mathrm{P})=0$. It follows that $\partial\left(\mathrm{W}_{\mathrm{i}} / \mathrm{P}\right) / \partial \mathrm{C}=-\varphi_{2} / \varphi_{1}>0$, as $\varphi_{2}>0$ and $\varphi_{1}=\mathrm{d} \varphi / \mathrm{dD}(1 / \mathrm{P})<0$ by the second order condition. Thus,

Proposition 1: The real wage level W/P is strictly increasing in the central increase C.

Observe that Proposition 1 depends crucially on the specification of the disagreement point of the parties in the local bargaining (Holden, 1989, Moene et al, 1993). If, in contrast to the assumptions here, the disagreement points of the parties were independent of the central wage increase, then the local wage bargaining would result in a unique equilibrium wage level W, where the wage drift would given residually, by what was necessary to reach this level. In this situation the central wage negotiations would be without importance for the actual wage level.

Whether the wage drift $\mathrm{D}$ is positive depends on which of the parties incur the larger costs during a work to rule. Measuring utility in wage units, a work to rule can be defined as more costly to the firm than to the union if the following condition holds

$$
\frac{\pi\left(\frac{W_{i}}{P}\right)-\pi_{0}\left(\frac{W_{-1}+C}{P}\right)}{-\pi^{\prime}\left(\frac{W_{i}}{P}\right)}>\frac{u\left(\frac{W_{i}}{P}\right)-u_{0}\left(\frac{W_{-1}+C}{P}\right)}{u^{\prime}\left(\frac{W_{i}}{P}\right)},
$$

for $\mathrm{W}_{\mathrm{i}}=\mathrm{W}_{-1}+\mathrm{C}$. If (5) holds, it can be seen from (4) that $\varphi>0$ for $\mathrm{W}_{\mathrm{i}}=\mathrm{W}_{-1}+\mathrm{C}$, thus the solution to (4), $\mathrm{D}_{\mathrm{i}}$, is strictly positive. The intuition is that the firm is willing to offer a nominal wage increase in order to prevent a costly dispute.

It seems plausible to assume that a work to rule is more costly to the firm than to the union; even with bonus schemes or piece rates, the workers usually have some choice in how 
to reduce productivity, and they will choose methods where the firm faces the higher costs (cf. Moene, 1988, and Holden, 1989). This is consistent with the fact that average wage drift in the manufacturing sector is strictly positive for all years and countries in my sample.

A special case is illuminating; assume that the workers are only concerned about wages, and that there are no bonus schemes, piece rates etc, so that $\mathrm{u}\left(\mathrm{W}_{\mathrm{i}} / \mathrm{P}\right)=\mathrm{W}_{\mathrm{i}} / \mathrm{P}$ and $\mathrm{u}_{0}\left(\left(\mathrm{~W}_{-1}+\mathrm{C}\right) / \mathrm{P}\right)=\left(\mathrm{W}_{-1}+\mathrm{C}\right) / \mathrm{P}$. Furthermore, during a work to rule, revenues $\mathrm{R}_{\mathrm{i}}$ are assumed to be a fraction $\theta \in(0,1)$ of their normal value, so $\pi_{0}\left(\left(\mathrm{~W}_{-1}+\mathrm{C}\right) / \mathrm{P}\right)=\theta \mathrm{R}_{\mathrm{i}}-\left(\mathrm{W}_{-1}+\mathrm{C}\right) \mathrm{L}_{\mathrm{i}}$, while $\pi_{\mathrm{i}}=$ $R_{i}-W_{i} L_{i}$ and $\pi^{\prime}=-L_{i}$. Substituting out in the first order condition (4), we can solve for the resulting wage level (omitting subscript $\mathrm{i}$ as all firms are identical)

$$
W=\frac{1-\theta}{2} \frac{R}{L}+W_{-1}+C .
$$

Thus there is no offset of the central wage increase, which has a unit coefficient on the actual wage level. (The wage drift is thus $\mathrm{D}=[(1-\theta) / 2] \mathrm{R} / \mathrm{L}$, ie independent of $\mathrm{C}$.)

\section{Central wage bargaining and nominal rigidities}

To explore the possibility of nominal rigidities, we need a slightly richer model of wage bargaining than what is normally used. There are three additional aspects that need to be included. First, the model must allow for the fact that a strike is not an automatic consequence of there being a delay in reaching an agreement. Production may continue while the parties are bargaining (which I shall refer to as a holdout, following Cramton and Tracy, 1992). In the Nordic countries, as in most other European countries, it is a well established practice that the terms of the old contract prevail during a holdout, even after the old contract has expired. (In Norway and Sweden, the parties are bound by the law to observe the old contract, unless a

negotiations, and this is the focus here. 
work stoppage is initiated).

Secondly, also a very short work stoppage may involve non-negligible costs to the parties (fixed costs; Holden, 1994). These costs may arise because the occurrence of a work stoppage may have an adverse effect on the future co-operation between workers and firms, or an adverse effect on the reputation of the firm, thus reducing productivity/profitability in the future. (Other interpretations will be discussed at length below.) If a work stoppage has taken place in the central negotiations, the payoffs of the parties when normal production is resumed are assumed to be $\pi(\mathrm{W} / \mathrm{P})-\mathrm{K}$, and $\mathrm{v}(\mathrm{W} / \mathrm{P})$, where $\mathrm{K}>0$ are the costs that are induced by the work stoppage.

Thirdly, in actual negotiations it seems unrealistic that one party may put the opponent in a position where a work stoppage is initiated automatically unless an offer is accepted. To prevent this possibility in the model, it must be designed so that the opponent is always allowed to make the last offer before a player may initiate a work stoppage. To capture these aspects as simply as possible, we set up the following model of the central negotiations (see Figure 1).

\section{Figure 1:}

Employer:

offer $C^{\mathrm{E}}$

Union:

reject/accept

$\downarrow$

Union: $\quad$ no work-st./work stoppage $\rightarrow$ alternating offers, incur K at agreement

Union: $\quad$ offer $\mathrm{C}^{\mathrm{U}}$

Employer: $\quad$ reject/accept $\quad \rightarrow$ game ends

Employer: $\quad$ no work-st./work stoppage $\rightarrow$ alternating offers, incur K at agreement

Holdout, alternating offers 
First, the employers' federation makes an offer, which the unions' federation may accept or reject. Acceptance ends the game, while upon a rejection, the unions are allowed to choose whether they want to strike. If they choose to strike, the remaining negotiations are modelled as a strategic bargaining model of the Rubinstein (1982) type; the parties receive (for simplicity) zero payoff until an agreement is reached, and they alternate in making offers. If the unions do not strike, they make an offer which the employers may accept or reject. Acceptance ends the game; after a rejection, it is the employers' turn to choose whether to initiate a lock-out. If a lock-out is chosen, the remaining negotiations are again modelled as a Rubinstein (1982) alternating offers model. If neither of the parties has chosen to initiate a work stoppage, there is a holdout until an agreement is reached. During a holdout, the players alternate in making offers, and their payoffs are given by the old contract.

The subgame perfect equilibrium (SPE) agreement is reached by the initial offer of the employers. However, to find the SPE outcome, we must analyse the game backwards. If a work stoppage is initiated, we have a standard Rubinstein game, and an immediate agreement will be reached. As shown by Binmore et al (1986), the outcome of the Rubinstein game is given by the Nash bargaining solution (assuming for simplicity that the players have equal discount factors). Thus, if a work stoppage has occurred, the outcome of the central bargaining is given by

$$
\mathrm{C}=\underset{\mathrm{C}}{\arg \max }\left\{\left[\pi\left(\left(\mathrm{W}_{-1}+\mathrm{C}+\mathrm{D}\right) / \mathrm{P}\right)-\mathrm{K}\right] \mathrm{v}\left(\left(\mathrm{W}_{-1}+\mathrm{C}+\mathrm{D}\right) / \mathrm{P}\right)\right\}
$$

where D is expected wage drift, which is equal to actual wage drift given by (4), as perfect 
foresight is assumed. The first order condition to (7) is

$$
\frac{\pi^{\prime}\left(\frac{W}{P}\right)\left(1+\frac{d D}{d C}\right) \frac{1}{P}}{\pi\left(\frac{W}{P}\right)-K}+\frac{v^{\prime}\left(\frac{W}{P}\right)\left(1+\frac{d D}{d C}\right) \frac{1}{P}}{v\left(\frac{W}{P}\right)}=0 .
$$

We assume that that a unique solution exists, which will hold for reasonable functional forms.

Observe that the functions in (7) and (8) only depend on the real wage level, and not of its components $\mathrm{W}_{-1}, \mathrm{C}, \mathrm{D}$ and $\mathrm{P}$. It follows that (8) can be solved for a real wage level $\omega^{\mathrm{S}}$, which is independent of the size of each of the individual components $\mathrm{W}_{-1}, \mathrm{C}, \mathrm{D}$ and $\mathrm{P}$, and of the effect of the central wage increase on the wage drift, $\mathrm{dD} / \mathrm{dC}$ (the $(1+\mathrm{dD} / \mathrm{dC}) / \mathrm{P}$ term in $(8)$ may be reduced). 4 The intuition is that the wage setters take the expected wage drift into account, and modify the central increase accordingly to maximise the Nash product. The central wage increase is given by $\omega^{S}=\left(W_{-1}+C^{S}+D\right) / P$, or equivalently, $C^{S}=P \omega^{S}-W_{-1}-D$. The resulting payoffs are $\pi\left(\omega^{\mathrm{S}}\right)-\mathrm{K}$ and $\mathrm{v}\left(\omega^{\mathrm{S}}\right)$.

If there is no work stoppage, the fixed costs are not incurred. Thus, the employers may pay a higher wage, and still obtain the same profit. Let this higher wage be $\omega^{\mathrm{E}}$, given by $\pi\left(\omega^{\mathrm{S}}\right)-\mathrm{K}=\pi\left(\omega^{\mathrm{E}}\right) . \mathrm{K}>0$ implies that $\omega^{\mathrm{E}}>\omega^{\mathrm{S}}$. In the appendix, I prove

4 If, in contrast to Proposition 1, wage drift were to completely offset the central wage increase so that $\mathrm{dD} / \mathrm{dC}=-1$, the first order condition (8) is satisfied for all $\mathrm{C}$, reflecting that the central wage increase is without importance. 
Proposition 2: There is a unique SPE real wage outcome (W/P) ${ }^{*}$ in the two-tiered system, given by

$$
\begin{aligned}
& =\omega^{E} \quad \text { if } \frac{W_{-1}+D}{P}>\omega^{E} \\
\left(\frac{W}{P}\right)^{*} & =\frac{W_{-1}+D}{P} \quad \text { if } \frac{W_{-1}+D}{P} \in\left[\omega^{S}, \omega^{E}\right] \\
& =\omega^{S} \quad \text { if } \frac{W_{-1}+D}{P}<\omega^{S}
\end{aligned}
$$

The central wage increase is given by $\mathrm{C}^{*}=(\mathrm{W} / \mathrm{P})^{*} \mathrm{P}-\mathrm{W}_{-1}-\mathrm{D}$.

Thus, if $\left(\mathrm{W}_{-1}+\mathrm{D}\right) / \mathrm{P}>\omega^{\mathrm{E}}$, the employers will use lock-out threats to press wages down. If $\left(\mathrm{W}_{-1}+\mathrm{D}\right) / \mathrm{P}<\omega^{\mathrm{S}}$, the unions use strike threats to raise wages. But there exists an interval $\left[\omega^{\mathrm{S}}\right.$, $\omega^{\mathrm{E}}$ ], such that if $\left.\left(\mathrm{W}_{-1}+\mathrm{D}\right) / \mathrm{P}\right)$ is within this interval, none of the parties may credibly threaten to initiate a work stoppage, and there will be given no wage increase in the central negotiations.

As the existence of this interval hinges on the assumption of fixed costs of a work stoppage, this assumption needs more discussion. First, observe that with straightforward modifications of the model one can show that the qualitative results are the same even if the fixed costs are only incurred after a lock-out (due to adverse effects on cooperation), and not after a strike. Likewise, the qualitative results do not hinge on whether the fixed costs fall on the firm only, or are shared by both parties. Secondly, note that if we extend the model slightly to allow for uncertainty, the fixed costs can be given a different interpretation. Assume that the bargaining outcome when a work stoppage has been initiated depends on the realisation of a random variable that is unknown to both parties ex ante, but which has a probability 
distribution that is common knowledge. This random variable may for example be the support/reaction of other agents (individual workers, local unions, employers, others) to the work stoppage. The expected wage outcome if a work stoppage is initiated is the same for both parties $\left(\omega^{\mathrm{S}}\right)$, but if the parties are risk averse, the employers will accept a higher wage with certainty, and the unions will accept a lower wage with certainty. The fixed costs may be interpreted as the amount that the parties are willing to give up so as to avoid risk (this argument is formalised in Holden, 1997).

In the comparison between the two-tiered system and a system with only central wage negotiations, I assume that the institutions governing the central negotiations are the same in both systems. The system with only central negotiations can then simply be represented by setting $\mathrm{D}=0$ in Proposition 2 .

Corollary: The relationship between the real wage outcome $(\mathrm{W} / \mathrm{P})^{\mathrm{C}}$ in the system with only central negotiations and $(\mathrm{W} / \mathrm{P})^{*}$, is given by
(i) $\left(\frac{W}{P}\right)^{C}=\left(\frac{W}{P}\right)^{*}=\omega^{E}$
if $\frac{W_{-1}}{P} \geq \omega^{E}$
(ii) $\left(\frac{W}{P}\right)^{C}<\left(\frac{W}{P}\right)^{*}$
if $\frac{W_{-1}+D}{P}>\omega^{S} \wedge \frac{W_{-1}}{P}<\omega^{E}$
(iii) $\left(\frac{W}{P}\right)^{C}=\left(\frac{W}{P}\right)^{*}=\omega^{S}$
if $\frac{W_{-1}+D}{P} \leq \omega^{S}$

A subcase of interval (ii) is

$$
\left(\frac{W}{P}\right)^{C}=\left(\frac{W}{P}\right)^{*}-\frac{D}{P}=\frac{W_{-1}}{P} \quad \text { if } \omega^{S} \leq \frac{W_{-1}}{P}<\frac{W_{-1}+D}{P} \leq \omega^{E}
$$


The two systems give the same real wage outcome in interval (i) (lock-out threats prevail in both systems) and interval (iii) (strike threats prevail in both systems). If neither of these cases apply (interval (ii)), the two-tiered system leads to higher real wages. In this case expected wage drift exceeds the target money wage growth, $\mathrm{D} / \mathrm{P}>\omega^{\mathrm{S}}-\mathrm{W}_{-1} / \mathrm{P}$, so that there is no room for money wage growth at the central negotiations. In other words, within this interval wages are rigid in nominal terms at the central level, thus expected wage drift is not fully reflected in the central agreement. In a subcase of (ii), holdout threats prevail in both systems, and there is no offset of expected wage drift in the central agreement. (If firms were different, so that drift would vary among the firms, then the two-tiered system and a system with only central negotiations would generally result in different outcomes.)

\section{Empirical evidence}

The investigation of whether wage drift offsets the central settlements is based on the following approach. First, I derive an empirical equation that may represent the wage outcome if the local wage negotiations were decisive in the wage determination. Then the central increase is included in the equation. If the local negotiations really are decisive, the central increase should have no impact on the wage outcome, and thus obtain a coefficient of zero. However, if there is no offset of the central increase in the local negotiations, the coefficient should equal unity. Figure 2 displays the central wage increase and the wage drift for the Nordic countries. [ Figure 2 about here]

I have used a general-to-specific approach, starting out from a standard real wage equation, adopted from Nymoen (1992):

$$
\Delta \mathrm{w}=\delta_{0}+\delta_{1}(\mathrm{w}+\mathrm{T}-\mathrm{q}-\mathrm{y})_{-1}+\delta_{2}(\mathrm{p}-\mathrm{q})_{-1}+\delta_{3} \mathrm{U}_{-1}+\delta_{4} \Delta \mathrm{U}+\delta_{5} \Delta \mathrm{q}+\delta_{6} \Delta \mathrm{y}+\delta_{7} \Delta \mathrm{p}+\delta_{8} \Delta \mathrm{T}
$$


where the $\delta_{\mathrm{i}}$ 's are constants, ${ }_{-1}$ denotes lagged one period, and the variables are (lowercase letters are used for variables measured in logarithms) w an index of money wages per hour for manual workers in the manufacturing sector (so $\Delta \mathrm{w}$ is central increase plus wage drift), $\mathrm{T}$ the employers' tax rate, $q$ the value added deflator in manufacturing, $p$ the consumer price index, $y$ a productivity index (manufacturing) and $\mathrm{U}$ the rate of unemployment (in the estimations I tried both a linear and a loglinear specification of unemployment). (w+T-q-y) and (p-q) are error correction terms, referring to the wage share and relative prices (the former should have a negative sign and the latter a positive). I have then proceeded by successive exclusion of explanatory variables based on sign and statistical precision of the estimates, with the aim of obtaining a well-specified and parsimonious empirical equation (see Table 1). For space considerations, I proceed directly to the main issue; Table 2 presents the results from including the central increase in the empirical equations in Table 1. For all countries, the coefficient of the central increase is significantly different from zero, and fairly close to unity (corresponding to the special case in equation (6) above). The high t-values indicate that the estimated coefficients are accurately determined. One should, of course, be cautious when interpreting this result, as there might exist other variables (eg expectations) that bias the coefficient. However, the general picture is the same when the central wage increase is treated as endogenous. These results clearly support the theoretical prediction that the existence of wage drift does not offset of the outcome of the central agreement.

Now consider the second issue of the paper, to what extent expected wage drift is reflected in the central negotiations. A thorough empirical investigation of this issue appears very demanding, in part due to the crucial problem of obtaining a satisfying empirical specification of the expected wage drift. At the early stage of this work, I tried several 
alternatives, including actual wage drift (instrumented) and fitted values from various wage drift regressions. However, the results were in some cases extremely sensitive to the rather arbitrary choice of which specification to use. Thus, the empirical analysis that is reported here has a more limited focus, where the lack of a variable capturing the expected wage drift seems less important. As is apparent from section IV, the interval (ii) where wages are higher in the two-tiered system arises as a consequence of nominal rigidity at the central negotiations. Thus, I test for the existence of nominal wage rigidity at the central negotiations; a positive finding would suggest that wages at times will be higher in the two-tiered system.

Let me start by summarising the crucial elements of the theoretical results in section IV that must be allowed for in an investigation of the existence of downward nominal rigidity. In years where the nominal rigidity is not binding (denoted $\mathrm{N}$ for normal; corresponding to intervals (i) and (iii) in the Corollary above ), the central wage increase is assumed to be given as a stable function of various economic variables. (I shall return to which variables below.) In years (denoted $\mathrm{R}$ for rigid; corresponding to interval (ii)) when this relationship results in a "too low" wage increase measured in nominal terms, a holdout takes place, and nominal rigidity is binding. In the model of section IV, the money wage then remains constant. However, in a more realistic model, a holdout need not always lead to constant nominal wages. First, if a holdout is costly to the firm, nominal wages will increase (cf. section III). Secondly, the parties may agree on Pareto-improving modifications to the existing agreement, for example that working rules are modified to raise productivity, and higher wages are given in exchange. These aspects are likely to vary from year to year, but are probably not well captured by any variable that can be used in the estimation. Thus, when nominal rigidity is binding, I shall assume that the nominal wage increase is equal to a time-invariant rate of wage growth, plus an error term. We observe the central increase, but we do not know which 
regimes applies.5 I want to test the null hypothesis that all years are normal, against the alternative hypothesis that nominal rigidity is binding in some years.

These considerations can be taken into account in a switching regression model,6

where

$$
\begin{aligned}
\mathrm{C}_{\mathrm{t}}^{\mathrm{N}} & =\mathrm{X}_{\mathrm{t}}^{\prime} \beta+\epsilon_{\mathrm{at}} \\
\mathrm{C}_{\mathrm{t}}^{\mathrm{R}} & =\alpha+\epsilon_{\mathrm{bt}} \\
\mathrm{C}_{\mathrm{t}} & =\max \left[\mathrm{C}_{\mathrm{t}}^{\mathrm{N}}, \mathrm{C}_{\mathrm{t}}^{\mathrm{R}}\right],
\end{aligned}
$$

and where $X_{t}$ and $\beta$ are vectors of explanatory variables and coefficients, respectively, $\alpha$ is a constant, and $\epsilon_{\mathrm{at}}$ and $\epsilon_{\mathrm{bt}}$ are error terms, assumed to be independent of each other and over time, and jointly normally distributed with variances $\sigma_{\mathrm{a}}{ }^{2}$ and $\sigma_{\mathrm{b}}{ }^{2}$. We observe $\mathrm{C}_{\mathrm{t}}$, but do not know which of the mechanisms that is binding. The likelihood of an observation $\left(\mathrm{X}_{\mathrm{t}}, \mathrm{C}_{\mathrm{t}}\right)$ is

$$
f\left(C_{t} \mid X_{t}\right)=\Phi(h) \frac{1}{\sigma_{a}} \phi\left(\frac{C_{t}-X_{t^{\prime}} \beta}{\sigma_{a}}\right)+(1-\Phi(h)) \frac{1}{\sigma_{b}} \phi\left(\frac{C_{t}-\alpha}{\sigma_{b}}\right)
$$

where $\Phi($.$) and \phi($.$) are the standard normal distribution and density functions, and$ $\mathrm{h}=\left(\mathrm{X}_{\mathrm{t}}^{\prime} \beta-\alpha\right) /\left({\sigma_{\mathrm{a}}}^{2}+{\sigma_{\mathrm{b}}}^{2}\right)^{1 / 2}$. Within the model (10a)-(10c), the null hypothesis that all years are normal corresponds to the assumption that (10a) prevails in all years. As is apparent from (11), this hypothesis can be seen as implied by a parameter restriction to the general model

5 This framework neglects the theoretical possibility of money wage cuts due to binding lockout threats, but this has no empirical relevance in my sample, as the central wage increase is positive in all observations in my sample.

6 The main area of application for the switching regression model has been disequilibrium economics, but it has also been used in a similar empirical analysis of wage determination by Lilja and Santamäki (1988). However, Lilja and Santamäki (1988) do not nest the two hypotheses to obtain an explicit test for the existence of nominal wage rigidity. Maddala (1983) provides an extensive discussion of the econometric properties of the model. 
(10a)-(10c), that $\alpha=-100$ (or an arbitrary large negative number), which entails that the probability that the normal wage setting (10a) prevails, $\Phi(h) \approx 1$. Thus, it is possible to test $\mathrm{H}_{0}$ by a Likelihood ratio test of model (10a) versus model (10a)-(10c).

To determine which explanatory variables to include for each country, I have used a general-to-specific method for model (10a), starting out from the standard real wage equation (9), with the modification that the dependent variable is the central wage increase and not the total wage growth. As above, explanatory variables are eliminated successively based on sign and statistical precision of the coefficient, until a parsimonious and empirically satisfying equation is obtained. This analysis is undertaken in PC-Give, without any allowance for a possible nominal wage rigidity (ie model (10a) is viewed in isolation). The same explanatory variables are used in model (10a)-(10c), the additional elements to (10a) are the alternative mechanism (10b) and the procedure (10c). Undertaking the selection process without allowing for nominal rigidity is of course a valid procedure under the null hypothesis, with no nominal rigidity.7

As discussed above, in the present analysis the expected wage drift is never included. Thus, the equation should be thought of as a reduced form, where, say, the coefficient of unemployment includes both the direct effect of unemployment on the central increase and the indirect effect via the expected wage drift.

The empirical results of model (10a) and model (10a)-(10c) are displayed in Tables 3 and 4. Again, I focus on the main issue, the test of whether nominal rigidity has been binding.

7 Three exceptions are made to this procedure. For Norway, unemployment is included due to the strong theoretical presumption that unemployment affects wages. Furthermore, I have included two variables that are on the borderline: the change in consumer prices (Norway) and the change in the value added deflator (Finland). 
The results of the Likelihood-ratio tests are shown at the bottom of Table 4 . The null hypothesis of no nominal rigidity is rejected for all countries, for Sweden at the 5 percent level, for the other countries at the 1 percent level. This lends support to the empirical relevance of interval (ii) (cf. the Corollary), where wages are higher in the two-tiered system than in a system with only central wage setting. The rate of money wage growth at which the downward nominal rigidity is binding varies among the countries from 1.5 percent in Denmark and Norway to 3.9 percent in Sweden (but with considerable year to year variation, as can be seen from the standard deviation in years when nominal rigidity is binding, $\sigma_{\mathrm{b}}$ ).

Figure 3 illustrates the results from the switching regression model in Table 4 by displaying the fitted values conditional on the wage setting being normal ("cnor") and rigid ("crig"), in addition to the actual central increase ("cw1"); the additional letter, D,F, N and S, indicates country. Recall that the estimated probability that normal wage setting prevails in an observation $\left(\mathrm{X}_{\mathrm{t}}, \mathrm{C}_{\mathrm{t}}\right)$ is $\Phi\left(\mathrm{h}_{\mathrm{t}}\right)$, where $\mathrm{h}_{\mathrm{t}}=\left(\mathrm{X}_{\mathrm{t}}^{\prime} \beta-\alpha\right) /\left({\sigma_{\mathrm{a}}}^{2}+\sigma_{\mathrm{b}}{ }^{2}\right)^{1 / 2}$, and where the parameter values are replaced by the estimated coefficients. Thus, the estimated probability that nominal rigidity is binding in a specific observation is greater than 50 per cent if cnor is less than crig. For Denmark, this is the case in 1983, where the estimated probability that wage setting was rigid was 0.98; for Finland, the corresponding probability was 0.52 in 1991 and 0.65 in 1992; and for Norway, it was 0.92 in 1979, 0.63 in 1985, and 0.54 in 1991. For Sweden, the results indicate that nominal rigidity has been binding throughout most of the sample period, with only eight observations where the estimated probability of rigid wage setting is below 50 per cent (cnorS > crigS in 1965, 1970, 1973-75, 1979-1981). This interpretation of Swedish wage setting may seem implausible; a related interpretation of the results would be that the 
switching regression model captures the specific functional form, where wage growth is more sensitive upwards than downwards (so that under the appropriate circumstances, wage growth may easily become very high, while wage growth is less sensitive at lower levels). Note however that the fitted value representing normal wage setting, cnor, cannot be taken as an estimate of wage growth over the sample period if there were no nominal rigidities. For example, a four per cent nominal wage reduction in Sweden in 1963 would have led to different values of the right hand side variables in the subsequent observations, and thus led to different prediction in later years. [ Figure 3 about here]

According to the theory model above, nominal rigidity will be binding in years when expected wage drift exceeds the target money wage increase. This aspect is difficult to evaluate without a satisfying empirical specification of expected wage drift. A possible way to proceed would be to undertake a detailed study, on annual basis, of the economic situation at the time when the central negotiations take place. This is an interesting avenue for future research, but it is outside the scope of the present study.

\section{Concluding remarks}

Previous literature has argued that the central wage setters may take the expected wage drift into account in the central negotiations, and that the wage drift does not completely offset the outcome of the central negotiations. The present paper provides empirical support for this view for the major Nordic countries. For all countries, there is no or a small offset of the central increase in the wage drift.

The paper also shows theoretically that as long as there is room for a money wage increase at the central negotiations, the two-tiered wage setting system works in the same way 
as a system with only central negotiations. However, if expected wage drift exceeds the target nominal wage growth (which for example could be the case in periods where low productivity growth and low inflation are combined with a sizeable wage drift), a reduction in money wages in the central agreement may be required for the two systems to be equivalent. If nominal rigidity exists at the central level, the total wage increase can be higher in a two-tiered system than it would have been in a system with only central wage setting.

The possible existence of a floor on money wage growth in the central wage negotiations receives considerable support in the empirical investigation. Within a framework of a switching regression model, the hypothesis of no downward nominal rigidity is rejected for all countries. The estimated floor on money wage growth varies among the countries from 1.5 percent in Denmark and Norway, 2.6 percent in Finland, to 3.9 percent in Sweden. In particular for Sweden, it may however be questioned whether the results in fact indicate nominal rigidity, or whether they capture the functional form of the wage setting process.

\section{Data appendix.}

Data for the centrally negotiated wage increase and the wage drift are obtained from the respective employers' associations. These data refer to manual workers in the manufacturing sector. The data for year $t$ represent annual increases from 2. quarter year $t$ to 2 . quarter $t+1$ (Denmark and Sweden), 4. quarter year $\mathrm{t}-1$ to 4 .quarter year $\mathrm{t}$ (Finland) and 1. quarter year $\mathrm{t}$ to 1.quarter year $\mathrm{t}+1$ (Norway). The wage index is calculated on the basis of the figures for the central increase and the wage drift. Note that the wage level in the 2 . quarter in year $t$ for Denmark and Sweden, 1. quarter of year t for Norway and 4. quarter in year t-1 for Finland is defined as the wage level in year $\mathrm{t}-1$ ( $\mathrm{w}_{-1}$ in the estimations). For the other variables, subscript ${ }_{-1}$ indicates average over year $\mathrm{t}-1$. 
q Value added deflator in manufacturing. Source: Norges Bank.

The other variables are based on the OECD-CEP data set, from the Centre for Economic Performance, LSE, for Finland and Norway updated after 1988 using the same sources (exceptions are noted below). The OECD-CEP data set uses the following sources (for more details, see Centre for Economic Performance, Working Paper 118, 1991):

p Consumer price index from Economic Outlook Historical Statistics.

T Employment tax rate is Employers' Social Security Contributions as a share of Compensations of Employees less Employers' Social Security Contributions from UN National Accounts Yearbook.

y Productivity index, for Denmark, Finland and Norway calculated from the index for industrial production in manufacturing and manufacturing employment from OECDCEP, from OECD Main Economic Indicators, and ILO Yearbook of Labour Statistics, for Sweden, from Calmfors (1990), figure 2a.

U Unemployment rate whole economy, OECD Labour Force Statistics.

Dummy for first year of central agreement: From Scheuer (1992) (for Denmark) and the country papers in Calmfors (1990)

Proof of Proposition 2: (Sketch) To find the SPE outcome, we must analyse the game backwards. If no work stoppage is initiated, the outcome of the bargaining is trivial. A holdout involves no cost to the parties compared to the old contract, so they will agree on a prolongation of the old nominal contract. $\mathrm{C}=0$, and the real wage outcome is $\left(\mathrm{W}_{-1}+\mathrm{D}\right) / \mathrm{P}$.

If a work stoppage is initiated, there will (as analysed in the main text) be an agreement giving a real wage $\omega^{\mathrm{S}}$. The resulting payoffs are $\pi\left(\omega^{\mathrm{S}}\right)-\mathrm{K}$ and $\mathrm{v}\left(\omega^{\mathrm{S}}\right)$.

The employers will initiate a lock-out if this is more profitable than the holdout 
solution, ie if and only if $\left(\mathrm{W}_{-1}+\mathrm{D}\right) / \mathrm{P}>\omega^{\mathrm{E}}$, where $\omega^{\mathrm{E}}$ is given by $\pi\left(\omega^{\mathrm{S}}\right)-\mathrm{K}=\pi\left(\omega^{\mathrm{E}}\right)$. Considering the unions' offer, they will demand the highest wage that the employers will accept, which will be given by $\min \left[\left(\mathrm{W}_{-1}+\mathrm{D}\right) / \mathrm{P}, \omega^{\mathrm{E}}\right]$, and this will be accepted by the employers.

Turning now to the unions' strike decision, a strike will be initiated if and only if this gives a higher wage than the holdout solution, ie that $\left.\omega^{\mathrm{S}}>\left(\mathrm{W}_{-1}+\mathrm{D}\right) / \mathrm{P}\right)$. (As shown above, the employers will clearly not initiate a lock-out if $\left.\omega^{\mathrm{S}}>\left(\mathrm{W}_{-1}+\mathrm{D}\right) / \mathrm{P}\right)$, so this alternative need not be considered). Finally, consider the employers' initial offer. They know that the unions cannot ensure themselves more than $\max \left[\left(\mathrm{W}_{-1}+\mathrm{D}\right) / \mathrm{P}, \omega^{\mathrm{S}}\right]$, so there is no need to offer more than this. However, if $\left(\mathrm{W}_{-1}+\mathrm{D}\right) / \mathrm{P}>\omega^{\mathrm{E}}>\omega^{\mathrm{S}}$, the employers may obtain $\pi\left(\omega^{\mathrm{E}}\right)$ by initiating a lock-out, so in this case the employers will offer $\omega^{\mathrm{E}}$ which is accepted by the unions.

It is straightforward to check that any deviation from the strategies above that would alter the outcome is inoptimal. 


\section{REFERENCES}

Binmore, K., Rubinstein, A. and Wolinsky, A.: The Nash bargaining solution in economic modelling. Rand Journal of Economics 17, 176-188, 1986.

Calmfors, L.: Wage formation and macroeconomic policy in the Nordic countries. L. Calmfors (ed). SNS and Oxford University Press, 1990.

Calmfors, L.: Lessons from the macroeconomic experience of Sweden. European Journal of Political Economy 9, 25-72, 1993.

Cramton, P.C. and Tracy, J.S.: Strikes and holdouts in wage bargaining. Theory and data. American Economic Review 82, 100-121, 1992.

Doornik, J.A. and H. Hansen.: A practical test of multivariate normality. Unpublished paper, Nuffield College, 1994.

Engle, R.F.: Autoregressive conditional heteroscedasticity, with estimates of the variance of United Kingdom inflations. Econometrica 50, 987-1007, 1982.

Flanagan, F.: Centralized and Decentralized pay determination in Nordic countries. In Wage formation and macroeconomic policy in the Nordic countries. L. Calmfors (ed). SNS and Oxford University Press, 1990.

Hansen, B.E.: Testing for parameter instability in linear models. Journal of Policy Modelling 14, 517-533, 1992.

Harvey, A.C.: The Econometric Analysis of Time Series. Deddington: Phillip Allan, 1981.

Hersoug, T. Kjær, K and Rødseth, A.: Wages, taxes and the utility-maximizing trade union: a confrontation with Norwegian data. Oxford Economic Papers 38, 403-423, 1986. 
Hibbs, D. and Locking, H.: Wage compression, wage drift and wage inflation in Sweden. Labour Economics 3, 109-141, 1996.

Holden, S.: Local and central wage bargaining. Scandinavian Journal of Economics 90, 93-99, 1988.

Holden, S.: Wage drift and bargaining: Evidence from Norway. Economica 56, 419-432, 1989.

Holden, S.: Economic policy in an economy with local and central wage bargaining. Memorandum 8, Department of Economics, University of Oslo, 1991.

Holden, S.: Wage bargaining and nominal rigidities. European Economic Review 38, 1021 1039, 1994.

Holden, S.: Renegotiation and the efficiency of investments. Mimeo, Department of Economics, University of Oslo, 1997.

Holden, S. and T. Birkeland: Wage drift and the irrelevance of centralised wage setting. Memorandum 1, Department of Economics, University of Oslo, 1995.

Holmlund, B.: Centralized wage setting, wage drift and stabilization policies under trade unionism. Oxford Economic Papers 38, 1986.

Holmlund, B. and Skedinger, P.:Wage bargaining and wage drift: Evidence from the Swedish wood industry. In Wage formation and macroeconomic policy in the Nordic countries. L. Calmfors (ed). SNS and Oxford University Press, 1990

Jackman, R.:Wage formation in the Nordic countries viewed from an international perspective. In Wage formation and macroeconomic policy in the Nordic countries. L. Calmfors (ed). SNS and Oxford University Press, 1990 
Johansen, K.: Dynamic modelling of the wage formation process in a two-tier bargaining system. Mimeo, University of Trondheim, 1995.

Lilja, R. and T. Santamäki: Dwnward stickiness of wages in Finnish industries - How resistant are wages to market pressure?. Discussion Paper 80, Labour Institute of Economic Research, Helsinki, 1988.

Lindbeck, A.: The Swedish experience. Seminar Paper 482. Institute of International Economic Studies. University of Stockholm, 1990.

Maddala, G.S.: Limited dependent and qualitative variables in econometrics. Cambridge University Press, Cambridge, 1983.

Moene, K.O.: Union threats and wage determination. Economic Journal 98, 471-483, 1988.

Moene, K.O., M. Wallerstein, and M. Hoel: Bargaining structure and economic performance. I Flanagan, R.J. K.O. Moene and M. Wallerstein: Trade Union Behaviour, Pay-Bargaining, and Economic Performance. Oxford University Press, 1993.

Nymoen, R.: Finnish manufacturing wages 1960-1987: Real wage flexibility and hysteresis. Journal of Policy Modeling 14, 429-451, 1992.

Rubinstein, A.: Perfect equilibrium in a bargaining model. Econometrica 50, 207-211, 1982.

Rødseth, A.: Centralized unions and macroeconomic policy: A note. Memorandum 10, University of Oslo, Department of Economics, 1985.

Sargan, J.D.: Wages and prices in the United Kingdom: A study in econometric methodology. In Hart, P., G. Mills and J.K. Whitaker (eds). Econometric Analysis for National Economic Planning, Vol 16 of Colston Papers, 25-63, 1964. 
Scheuer, S.: Denmark: Return to decentralization. In Ferner, A. and Hyman, R.: Industrial Relations in the New Europe, Oxford: Basil Blackwell, 1992.

Skånland, H.: Kan vi velge vår fremtid? (Can we choose our future?). Penger and Kreditt 4, Bank of Norway, 1983. 
TABLE 1

Modelling total wage increase $\Delta \mathrm{w}$ by OLS

\begin{tabular}{|c|c|c|c|c|}
\hline & $\begin{array}{l}\text { Denmark } \\
1961-1989\end{array}$ & $\begin{array}{l}\text { Finland } \\
1961-1992\end{array}$ & $\begin{array}{l}\text { Norway } \\
1961-1992 \\
\end{array}$ & $\begin{array}{l}\text { Sweden } \\
1961-1985\end{array}$ \\
\hline Constant & $\begin{array}{l}0.331 * \\
(2.98)\end{array}$ & $\begin{array}{l}-0.142 \\
(1.17) \\
\end{array}$ & $\begin{array}{l}-0.541 * \\
(3.15) \\
\end{array}$ & $\begin{array}{l}0.338 * \\
(2.113) \\
\end{array}$ \\
\hline$(w+T-y-q)_{-1}$ & & $\begin{array}{l}-0.133 \\
(1.69)\end{array}$ & $\begin{array}{l}-0.221 * \\
(3.37)\end{array}$ & \\
\hline$\Delta \mathrm{q}$ & & $\begin{array}{l}0.448^{*} \\
(4.41)\end{array}$ & $\begin{array}{l}0.766^{*} \\
(2.59)\end{array}$ & $\begin{array}{l}0.339 * \\
(3.15)\end{array}$ \\
\hline$\Delta \mathrm{y}$ & & & & $\begin{array}{l}0.337^{*} \\
(2.15)\end{array}$ \\
\hline$\Delta \mathrm{p}$ & $\begin{array}{l}0.870^{*} \\
(4.62)\end{array}$ & $\begin{array}{l}0.486^{*} \\
(3.12)\end{array}$ & $\begin{array}{l}0.964 * \\
(2.80) \\
\end{array}$ & \\
\hline $\begin{array}{l}\mathrm{U}_{-1} \\
\text { Finland } \mathrm{U}_{-2}\end{array}$ & $\begin{array}{l}-1.243^{*} \\
(5.87)\end{array}$ & $\begin{array}{l}-0.748 * \\
(2.31)\end{array}$ & & $\begin{array}{l}-4.764^{*} \\
(4.001)\end{array}$ \\
\hline $\begin{array}{l}\Delta \mathrm{U} \\
\text { Finland } \Delta \mathrm{U}_{-1}\end{array}$ & $\begin{array}{l}-0.954 * \\
(2.37) \\
\end{array}$ & $\begin{array}{l}-1.216^{*} \\
(2.88) \\
\end{array}$ & $\begin{array}{l}-2.702 * \\
(2.50)\end{array}$ & $\begin{array}{l}-3.117^{*} \\
(2.58) \\
\end{array}$ \\
\hline$(p-q)_{-1}$ & $\begin{array}{l}0.141 * \\
(2.33) \\
\end{array}$ & & & $\begin{array}{l}0.142 \\
(1.59) \\
\end{array}$ \\
\hline $\mathrm{R}^{2}$ & 0.733 & 0.817 & 0.615 & 0.683 \\
\hline$\sigma$ & 0.022 & 0.023 & 0.032 & 0.016 \\
\hline Autocor. & $2.45[0.10]$ & $0.99[0.38]$ & $2.55[0.09]$ & $1.64[0.22]$ \\
\hline $\mathrm{ARCH}$ & $0.82[0.37]$ & $0.009[0.92]$ & $0.16[0.68]$ & $0.04[0.82]$ \\
\hline Normality & $1.04[0.59]$ & $5.36[0.06]$ & $7.41 *[0.02]$ & $1.13[0.56]$ \\
\hline
\end{tabular}

Notes: T-values in parenthesis, p-values in square brackets. ${ }_{-1}$ denotes lagged one period, * indicates significance at 5\% level, and the variables are (lowercase letters denote logarithms) $\mathrm{w}$ an index of money wages per hour, $\mathrm{T}$ the employers' tax rate, $\mathrm{q}$ value added deflator, $\mathrm{p}$ consumer price index, y productivity index and $U$ rate of unemployment. Autocor. is a test for error autocorrelation from lags 1 to 2 (Harvey, 1982); ARCH is a test of autoregressive conditional heteroscedasticity (Engle, 1982); Normality of residuals Doornik and Hansen (1994). With the exception of the coefficient for $U_{-1}$ for Sweden, none of the parameters are revealed as non-constant within the sample (Hansen, 1992), and the corresponding joint parameter instability test is passed for all countries (see further description in the manual of PC-Give 8.0). 


\section{TABLE 2}

Including the central wage increase in Table 1

\begin{tabular}{||l|l|l|l|l||}
\hline & Denmark & Finland & Norway & Sweden \\
\hline $\mathrm{C} / \mathrm{W}_{-1}$ (OLS) & $\begin{array}{l}0.892^{*} \\
(4.59)\end{array}$ & $\begin{array}{l}0.783^{*} \\
(7.22)\end{array}$ & $\begin{array}{l}1.012^{*} \\
(10.85)\end{array}$ & $\begin{array}{l}0.785^{*} \\
(4.68)\end{array}$ \\
\hline $\mathrm{C} / \mathrm{W}_{-1}$ (IV) & $\begin{array}{l}0.850 * \\
(2.92)\end{array}$ & $\begin{array}{l}0.739 * \\
(3.83)\end{array}$ & $\begin{array}{l}0.994^{*} \\
(7.49)\end{array}$ & $\begin{array}{l}1.082 * \\
(4.13)\end{array}$ \\
$\begin{array}{l}\text { Specification } \\
\mathrm{Chi}^{2}\end{array}$ & $6.1[0.41]$ & $9.24[0.09]$ & $2.00[0.84]$ & $5.75[0.33]$ \\
\hline
\end{tabular}

Notes: $\mathrm{C} / \mathrm{W}_{-1}$ is the centrally negotiated wage increase relative to the lagged nominal wage level. In the IV estimation, $\mathrm{C} / \mathrm{W}_{-1}$ is treated as endogenous. Additional instruments used are $\left(\mathrm{C} / \mathrm{W}_{-1}\right)_{-1}, \Delta \mathrm{p}_{-1}, \Delta \mathrm{q}_{-1}, \Delta \mathrm{U}_{-1}$ (Finland: $\left.\Delta \mathrm{y}\right), \Delta \mathrm{y}_{-1}$, and dummy for first year of central agreement; for Denmark also $\Delta$ q. Specification $\mathrm{Chi}^{2}$ is a test for the validity of instruments based on Sargan (1964). In the IV estimation, the first observation is lost due to need for instruments. See also Table 1. 
TABLE 3

Modelling the central wage increase $\mathrm{C} / \mathrm{W}_{-1}$ by OLS

\begin{tabular}{|c|c|c|c|c|}
\hline & $\begin{array}{l}\text { Denmark } \\
1962-1989 \\
\end{array}$ & $\begin{array}{l}\text { Finland } \\
1961-1992 \\
\end{array}$ & $\begin{array}{l}\text { Norway } \\
1961-1992 \\
\end{array}$ & $\begin{array}{l}\text { Sweden } \\
1961-1985 \\
\end{array}$ \\
\hline Constant & $\begin{array}{l}-0.205^{*} \\
(3.09) \\
\end{array}$ & $\begin{array}{l}-0.030 \\
(1.12) \\
\end{array}$ & $\begin{array}{l}-0.492 * \\
(3.70) \\
\end{array}$ & $\begin{array}{l}0.068 \\
(0.90) \\
\end{array}$ \\
\hline$(w+T-y-q)_{-1}$ & $\begin{array}{l}-0.059 * \\
(2.02)\end{array}$ & & $\begin{array}{l}-0.179 * \\
(3.31)\end{array}$ & \\
\hline$\Delta \mathrm{q}$ & $\begin{array}{l}0.474^{*} \\
(3.12) \\
\end{array}$ & $\begin{array}{l}0.153 \\
(1.50) \\
\end{array}$ & $\begin{array}{l}0.720^{*} \\
(3.18) \\
\end{array}$ & $\begin{array}{l}0.207^{*} \\
(2.17) \\
\end{array}$ \\
\hline$\Delta \mathrm{p}$ & $\begin{array}{l}0.682 * \\
(3.49)\end{array}$ & $\begin{array}{l}0.303 * \\
(2.03)\end{array}$ & $\begin{array}{l}0.407 \\
(1.52)\end{array}$ & \\
\hline $\begin{array}{l}\ln (\mathrm{U}) \\
\text { Finl. } \ln (\mathrm{U})_{-2} \\
\end{array}$ & $\begin{array}{l}-0.028 * \\
(5.79)\end{array}$ & $\begin{array}{l}-0.015 * \\
(2.02)\end{array}$ & $\begin{array}{l}-0.006 \\
(0.70) \\
\end{array}$ & $\begin{array}{l}-0.051 * \\
(2.24)\end{array}$ \\
\hline$\Delta \ln (\mathrm{U})_{-1}$ & & $\begin{array}{l}-0.028 * \\
(2.03) \\
\end{array}$ & & \\
\hline$(p-q)_{-1}$ & & & & $\begin{array}{l}0.150 \\
(1.75) \\
\end{array}$ \\
\hline First year & & $\begin{array}{l}0.018^{*} \\
(2.11)\end{array}$ & $\begin{array}{l}0.030^{*} \\
(3.31) \\
\end{array}$ & \\
\hline $\mathrm{R}^{2}$ & 0.716 & 0.600 & 0.617 & 0.495 \\
\hline$\sigma$ & 0.017 & 0.022 & 0.025 & 0.015 \\
\hline Autocor. & $0.65[0.53]$ & $1.16[0.33]$ & $0.45[0.63]$ & $0.60[0.55]$ \\
\hline $\mathrm{ARCH}$ & $0.65[0.42]$ & $0.63 \quad[0.43]$ & $1.13[0.29]$ & $0.67[0.41]$ \\
\hline Normality & $1.35[0.50]$ & $10.61 *[0.005]$ & $5.70[0.05]$ & $0.86[0.65]$ \\
\hline
\end{tabular}

Notes: First year is a dummy for first year of the contract period of central agreement. None of the parameters are revealed as non-constant within the sample (Hansen , 1992), and the corresponding joint parameter instability test is passed for all countries. See also Tables 1 and 2 . 
TABLE 4

Modelling the central wage increase $\mathrm{C}_{\mathrm{W}} \mathrm{W}_{-1}$ in a switching regression model

\begin{tabular}{|c|c|c|c|c|}
\hline & $\begin{array}{l}\text { Denmark } \\
1962-1989 \\
\end{array}$ & $\begin{array}{l}\text { Finland } \\
1961-1992 \\
\end{array}$ & $\begin{array}{l}\text { Norway } \\
1961-1992 \\
\end{array}$ & $\begin{array}{l}\text { Sweden } \\
1961-1985 \\
\end{array}$ \\
\hline Constant $_{\mathrm{a}}$ & $\begin{array}{l}-0.303^{*} \\
(3.19)\end{array}$ & $\begin{array}{l}-0.0005 \\
(0.046) \\
\end{array}$ & $\begin{array}{l}-0.616^{*} \\
(3.04)\end{array}$ & $\begin{array}{l}0.312 \\
(1.01) \\
\end{array}$ \\
\hline$(w+T-y-q)_{-1}$ & $\begin{array}{l}-0.100 * \\
(2.11)\end{array}$ & & $\begin{array}{l}-0.224^{*} \\
(3.10)\end{array}$ & \\
\hline$\Delta \mathrm{q}$ & $\begin{array}{l}0.498 \\
(1.91) \\
\end{array}$ & $\begin{array}{l}0.187^{*} \\
(4.81)\end{array}$ & $\begin{array}{l}0.764 * \\
(2.80) \\
\end{array}$ & $\begin{array}{l}0.230 \\
(1.12) \\
\end{array}$ \\
\hline$\Delta \mathrm{p}$ & $\begin{array}{l}0.853^{*} \\
(3.42)\end{array}$ & $\begin{array}{l}0.232 * \\
(3.79)\end{array}$ & $\begin{array}{l}0.561 \\
(1.39)\end{array}$ & \\
\hline $\begin{array}{l}\ln (\mathrm{U}) \\
\text { Finl. } \ln (\mathrm{U})_{-2}\end{array}$ & $\begin{array}{l}-0.034^{*} \\
(5.88) \\
\end{array}$ & $\begin{array}{l}-0.005 \\
(1.52) \\
\end{array}$ & $\begin{array}{l}-0.004 \\
(0.50) \\
\end{array}$ & $\begin{array}{l}-0.190 \\
(1.49) \\
\end{array}$ \\
\hline$\Delta \ln (\mathrm{U})_{-1}$ & & $\begin{array}{l}-0.022 * \\
(3.01) \\
\end{array}$ & & \\
\hline$(p-q)_{-1}$ & & & & $\begin{array}{l}0.680 \\
(1.50)\end{array}$ \\
\hline First year & & $\begin{array}{l}0.007^{*} \\
(2.33)\end{array}$ & $\begin{array}{l}0.034 * \\
(2.82) \\
\end{array}$ & \\
\hline$\sigma_{a}$ & 0.015 & 0.005 & 0.024 & 0.014 \\
\hline Constant $_{\mathrm{b}}$ & $\begin{array}{l}0.015^{*} \\
(15.03) \\
\end{array}$ & $\begin{array}{l}0.026 \\
(1.306) \\
\end{array}$ & $\begin{array}{l}0.015 \\
(1.27) \\
\end{array}$ & $\begin{array}{l}0.039 * \\
(12.02) \\
\end{array}$ \\
\hline$\sigma_{\mathrm{b}}$ & 0.00075 & 0.061 & 0.0017 & 0.012 \\
\hline $\begin{array}{l}\text { Likelihood- } \\
\text { ratio }\end{array}$ & $9.72 *$ & $19.48 *$ & $15.04 *$ & $6.10 *$ \\
\hline
\end{tabular}

Notes: Estimation of model (10a)-(10c). Constant $\mathrm{t}_{\mathrm{a}}, \sigma_{\mathrm{a}}$, constant $\mathrm{b}_{\mathrm{b}}$ and $\sigma_{\mathrm{b}}$ are constant terms and standard errors in "normal" and "rigid" years, respectively. The likelihood-ratio is calculated as $-2 \mathrm{~L}$, where $\mathrm{L}=\mathrm{Log}$ likelihood of model (10a) (in Table 3) minus Log likelihood of model (10a)-(10c) (in Table 4). It has a $\mathrm{Chi}^{2}(1)$ distribution, where critical values are 3.85 (5 percent) and 6.63 (1 percent). See also Tables 1-3. 


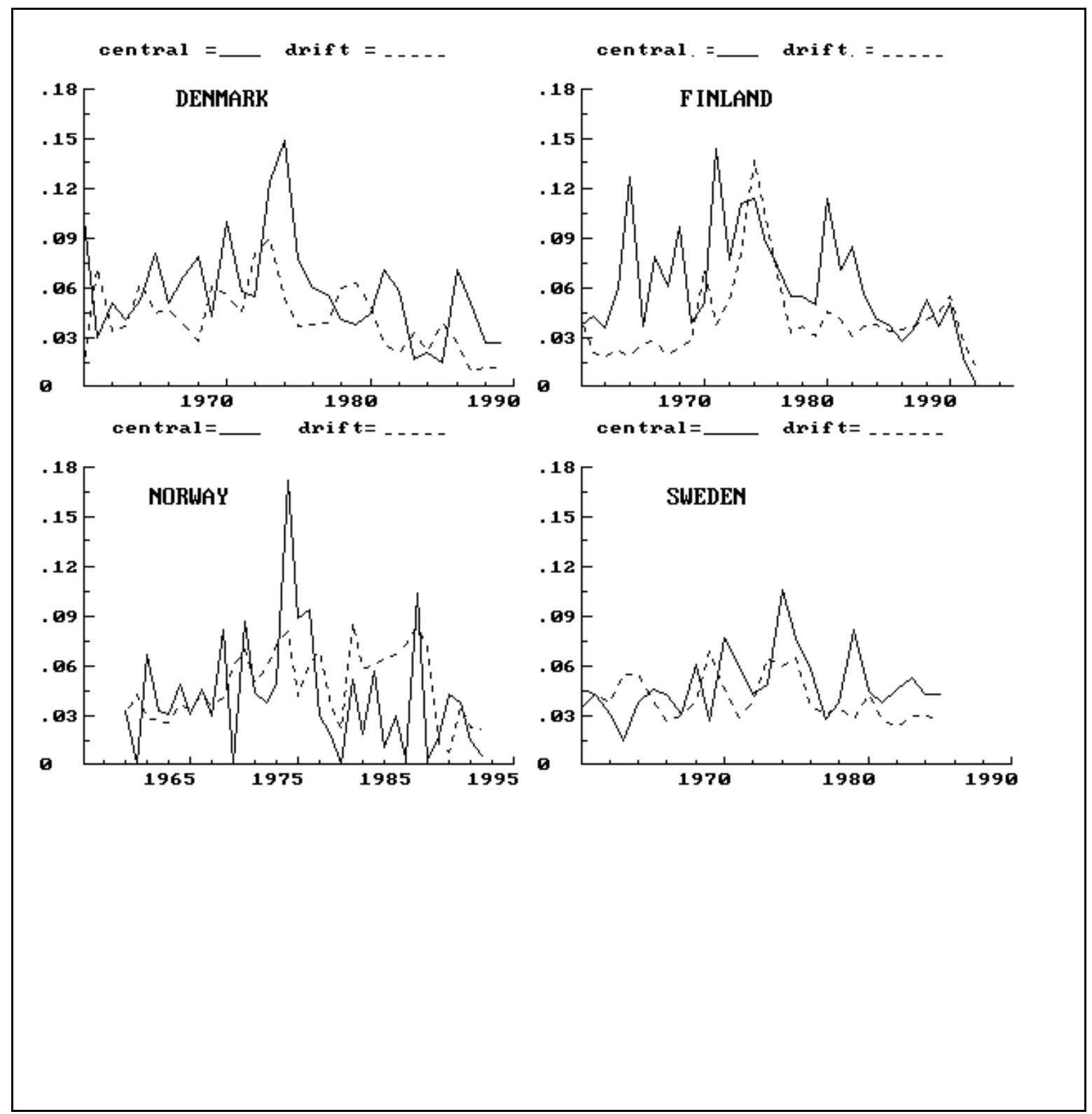

Figure 2: Wage drift and centrally negotiated wage increase from 1961 to 1985 (Sweden), 1989 (Denmark) and 1992 (Finland and Norway). For Denmark and Sweden, the end of the data period reflects that the employers' association no longer publishes data on central wage increase and wage drift. 

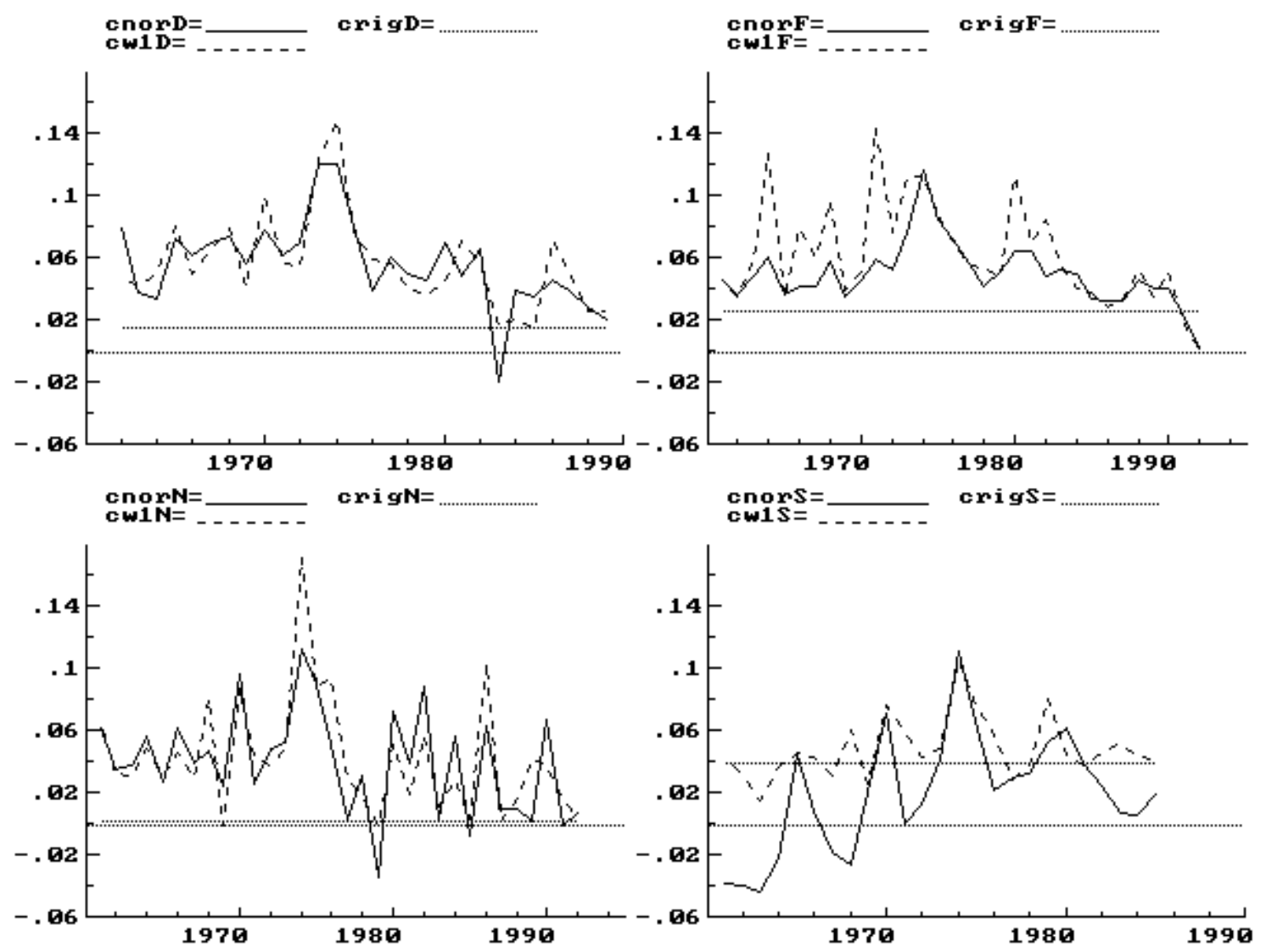

Figure 3: Fitted values from Table 4 in "normal" (cnor) and "rigid" years (crig), as well as the actual central increase cw1, for Denmark (D), Finland (F), Norway (N) and Sweden (S). 